Diabetologia 7, 334-338 (1971)

(C) by Springer-Verlag 1971

\title{
Kidney Function in Experimental Diabetic Ketosis*
}

\author{
M. HoHENEGGER and B. RUDAS \\ Institute for General and Experimental Pathology of the University of Vienna, Vienna, Austria
}

Received: April 18, 1971, accepted: July 22, 1971

Summary. Rats both with streptozotocin and alloxan diabetes were used. Ketosis developed in the first days following the application of the diabetogenic agents, and also in rats with long term diabetes in the first days after the insulin previously administered daily, had been withdrawn. The rats with more elevated blood ketone levels also demonstrated strikingly high serum urea levels, oliguria and a diminished food intake. In the groups of rats which in spite of insulin deficiency revealed no or only mild ketonaemia, food intake was increased, and marked polyuria as well as near to normal serum urea levels were observed. Our results showed that the symptoms of uraemia occurred independently of the nature of the diabetic agent, and also of the time at which these agents were administered. Thus it can be concluded that in that case acute renal insufficiency was not due to the nephrotoxicity of the agents employed but rather to the severity of diabetic ketosis.

La fonction rénale dans la cétose diabétique expérimentale Résumé. Des rats rendus diabétiques par application d'alloxane ou de streptozotocine ont été étudiés. La cétose est apparue dans les premiers jours après l'administration de l'agent diabétogène et aussi chez les rats ayant un diabète depuis longtemps après avoir cessé l'application d'insuline administrée quotidiennement auparavant. Les rats chez lesquels la cétonémie était la plus marquée présentaient une élévation frappante des taux d'urée sérique, accompagnés d'une oligurie et d'une diminution de prise de nourriture. Chez les rats qui malgré l'insuffisance d'insuline n'avaient qu'une cétonémie modérée, on a observé une consommation de nourriture élevée. Ils excrètaiont de grandes quantités d'urine et lour teneur en urée sérique était presque normale. Ces résultats ont montré que les symptômes d'urémie sont apparus indépendamment de la nature des agents diabótogènes et aussi du temps d'application de ces agents. Ainsi on peut conclure que l'insuffisance rénale aiguë dépend moins de la néphrotoxicité des agents employés que de l'intensité de la cétose diabétique. \section{Ketose \\ Die Nierenfunktion bei experimenteller diabetischer}

Zusammenfassung. Die Untersuchungen wurden an alloxan- und streptozotocindiabetischen Ratten durchgeführt. Eine Ketose entwickelte sich in den ersten Tagen nach der Applikation der diabetogenen Agentien sowie auch nach 4wöchiger Diabetesdauer, wenn das bis dahin täglich verabreichte Insulin entzogen wurde. Bei den Ratten, die eine starke Ketonämie aufwiesen, war auch der Serum-Urea-Spiegel außergewöhnlich hoch, die Tiere waren oligurisch und ihre Futteraufnahme war stark vermindert. Die Ratten, bei denen trotz des Insulinmangels keine oder eine nur milde Ketonämie auftrat, zeigten eine erhöhte Futteraufnahme, ausgeprägte Polyurie und nahezu normale Serumharnstoff-Werte. Unsere Versuche zeigten, daß das Auftreten von urämischen Symptomen von der Art der diabetogenen Substanzen und auch vom Zeitpunkt, zu dem diese verabreicht wurden, unabhängig war. So kann geschlossen werden, daß das akute Nierenversagen in diesem Falle weniger durch die Nephrotoxizität der verwendeten Substanzen, sondern vielmehr durch die Intensität der diabetischen Ketose bedingt war.

Key-words: Streptozotocin- and alloxan diabetes, insulin withdrawal, ketosis and uraemia, blood ketones, serum urea.
"One must be careful to distinguish between the direct effects of alloxan in animals and the secondary effects resulting from the alterations of the $\beta$-cells and insulin release. There have been many studies on animals made diabetic by the administration of alloxan, but such work is not within our province inasmuch as these secondary effects are related only to insulin deficiency and are typical of the diabetic state rather than the immediate actions of alloxan."

These sentences written in a recent review by Webb [16] apply expecially to the so-called nephrotoxic effect of alloxan following its application. The often fatal uraemia occuring characteristically during the first four days after alloxanization is generally accepted as the symptom of an acute and reversible alloxan poisoning $[8,10]$. It was even recommended

* Presented in part at the Jahresversammlung der Österreichischen Diabetes-Gesellschaft, Innsbruck 1970. that experiments with the animals should be carried out only about 2 weeks after alloxan had been administered. Kidney damage is supposed to have disappeared by this time since blood urea nitrogen has returned to normal values [9]. On the other hand, however, elevated blood urea nitrogen may also be found after pancreatectomy [4], and in rats treated with anti-insulin serum [17]. Earlier and more recent case reports on diabetic patients $[7,11,13]$ confirm the view [18] that acidosis in itself diminishes renal blood flow to such an extent that renal impairment results. Thus even without any nephrotoxic action uraemia could develop in ketotic rats. In a previous study we found a significant inverse correlation between blood $\mathrm{pH}$ and serum urea concentration $(r=-0.69 ; p<0.01)$ in alloxanized ketotic rats [2]. It is difficult, however, to establish a clear-cut distinction between the primary and secondary effects of alloxan in this case, since 
ketosis is present only for a few days following administration of alloxan.

The present experiments were designed to study the relationship between ketosis and uraemia in alloxan diabetic rats treated with insulin for 4 weeks. Upon withdrawal of insulin these rats become severely ketotic [14], but as mentioned previously it is claimed that renal damage is repaired by this time. Thus uraemia developing during that period of ketosis cannot be attributed to acute alloxan toxicity. We extended our investigations further to rats with streptozotocin-diabetes. In spite of the fact that unidentified renal disturbances were observed in the course of the clinical use of the drug [12], no nephrotoxic effect was reported in animals with streptozotocin-diabetes. In a previous study we showed that also following streptozotocin administration severe ketosis could develop in rats [6]. In the present study the rats with streptozotocin-diabetes were examined during the first days of the diabetic state as well as after insulin treatment in order to rule out, in this case too, the possibility of an acute nephrotoxic effect.

\section{Materials and Methods}

Male rats of a Wistar strain weighin $200-300 \mathrm{~g}$, maintained on Taco (Tagger, Graz) laboratory chow, were used. Alloxan-monohydrate (Loba-Chemie) was dissolved in $0.9 \%$ saline, final concentration $12 \%$, and injected subcutaneously in a dose of $180 \mathrm{mg} / \mathrm{kg}$ body weight. Streptozotocin (a gift from Upjohn Co., Kalamazoo, Michigan) was dissolved in citrate buffer $\mathrm{pH} 4.5 \mathrm{in}$ a concentration of $65 \mathrm{mg} / \mathrm{ml}$; and a dose of $65 \mathrm{mg} / \mathrm{kg}$ body weight were injected into a tail vein. Glycosuria was evaluated by Tes-Tape (Lilly) and ketonuria by Acetest tablets (Ames). Only rats which exhibited a $4+$ urine test for acetone were considered to be ketotic, and animals with trace amounts of ketone bodies were excluded from the experiments. Blood was obtained from the orbital sinus. Blood sugar was determined by the glucose oxidase technique, urea in serum by the method of Fawcett and Scott [5] using "Merckotest" reagents. Ketone bodies were measured in whole blood according to the method of Bessman and Anderson [3].

In the first experiment the blood sugar was determined 48 hours after the administration of the diabetogenic agents. On the 3rd or 4th day of the diabetic state the rats were put in metabolic cages for $24 \mathrm{~h}$ with free access to chow pellets and water. At the end of the 24-hour period, body weight and urine volume were checked, remaining food weighed and serum urea and blood ketone body levels were determined. Both the alloxanized and the streptozotocin-diabetic rats were divided into two groups: a) those without ketonuria and b) those with ketonuria. The results of this experiment are presented in table 1.

In Experiment 2 the rats were treated with insulin for 4 weeks beginning immediately after the induction of diabetes. They received daily 4 units of ZincProtamin-Insulin (a gift from Novo Industry A/S Copenhagen) subcutaneously, and where necessary, the daily doses were raised to 8 units. On the last day of insulin treatment the rats were put in metabolic cages for $24 \mathrm{~h}$; body weight, food intake and urine volume were checked and serum urea was determined. After cessation of insulin treatment all the rats showed ketonuria, lost weight and some of them died. Blood sugar was determined 48 hours after the last insulin injection. On the 3rd or 4th day of insulin deprivation the rats were again put in metabolic cages and the above examinations, and also determination of blood ketone concentration, were carried out. According to the degree of ketonaemia the results obtained in this experiment were divided into two groups: a) rats with ketone body concentration under $30 \mathrm{mg} \%$, and $\mathrm{b}$ ) rats with ketone body concentrations above $30 \mathrm{mg} \%$. The results of Experiment 2 are given in table 2. All the values are presented as mean \pm standard errors of mean.

\section{Results}

Exp. 1. As shown in table 1 both in alloxan- and streptozotocin-diabetes the rats with ketonuria showed, apart from the higher blood ketone levels, also markedly higher serum urea concentrations than those without ketonuria $(p<0.01)$. The output of urine and the food intake in the ketotic rats was low in comparison with that found in the nonketotic animals. This picture, well known in ketotic, alloxanized rats, has to our knowledge not yet been reported in rats with streptozotocin diabetes. The only significant difference between the two diabetes models in our experiment was a lower blood sugar observed in the rats with streptozotocin diabetes $(p=0.05)$.

Exp. 2. It can be seen from table 2 that although food intake and urine volume were normal under insulin treatment, somewhat elevated serum urea levels were found in those rats which later became severely ketotic upon insulin withdrawal. The serum urea levels in these rats, however, increased 4- and 5 -fold without any increase of the urine excretion when insulin was discontinued, thus demonstrating the effect of insulin deficiency and severe ketosis on the development of uraemia. In the groups of rats which had a lower mean concentration of ketone bodies in the blood after insulin withdrawal, near to normal levels of serum urea and marked polyuria were observed. Some difference could be observed between the alloxanized- and streptozotocin-diabetic rats in the volume of urine excreted under insulin treatment, but the response to insulin withdrawal has been closely similar in both groups. Some rats were examined on two consecutive days after insulin withdrawal, and in table 3 we present the detailed data of one ketotic rat from both the alloxan- 
and the streptozotocin-diabetes groups. It can be seen that elevation of the concentrations of blood ketone and serum urea, associated with a marked weight loss, oliguria and decreased food intake, developed in the
The histological examinations of the kidneys of rats with uraemia revealed cloudy swelling and a fine vacuolization of the tubular cells, and also the presence of protein casts in some of the tubular lumina.

Table 1. The effect of the application of alloxan or streptozotocin on the blood glucose, ketone body and serum urea concentrations, urine volume and food intake

\begin{tabular}{|c|c|c|c|c|c|c|c|}
\hline Group & Ketonuria & $\begin{array}{l}\text { No } \\
\text { of rats }\end{array}$ & $\begin{array}{l}\text { Glucose } \\
\mathrm{mg} / 100 \mathrm{ml}\end{array}$ & $\begin{array}{l}\text { Total ketone } \\
\text { Acetone } \\
\mathrm{mg} / 100 \mathrm{ml}\end{array}$ & $\begin{array}{l}\text { Serum urea } \\
\mathrm{mg} / 100 \mathrm{ml}\end{array}$ & $\begin{array}{l}\text { Urine volume } \\
\mathrm{ml} / 24 \mathrm{~h}\end{array}$ & $\begin{array}{l}\text { Food intake } \\
\mathrm{g} / 24 \mathrm{~h}\end{array}$ \\
\hline \multirow{2}{*}{$\begin{array}{l}\text { Alloxan } \\
\text { diabetes }\end{array}$} & none & 8 & $417 \pm 25$ & $11 \pm 2.2$ & $57 \pm 10$ & $63 \pm 11$ & $17 \pm 1$ \\
\hline & ++++ & 9 & $430 \pm 16^{\mathrm{c}}$ & $67 \pm 10.0^{\mathrm{b}}$ & $187 \pm 39 a$ & $12 \pm 2^{b}$ & $4 \pm 0.4^{b}$ \\
\hline \multirow{2}{*}{$\begin{array}{l}\text { Streptozotocin } \\
\text { diabetes }\end{array}$} & none & 9 & $323 \pm 24$ & $10 \pm 1.2$ & $39 \pm 5$ & $80 \pm 15$ & $18 \pm 1$ \\
\hline & $+t+t$ & 10 & $325 \pm 19^{c}$ & $48 \pm 6.0^{\mathrm{b}}$ & $178 \pm 33^{\mathrm{b}}$ & $21 \pm 3^{b}$ & $5 \pm 1^{b}$ \\
\hline
\end{tabular}

Statistical evaluation: rats with ketonuria versus rats without ketonuria.

a $p<0.01$

b $p<0.001$

c No significance

Table 2. The effect of insulin withdrawal on the blood glucose, ketone body and serum urea concentrations, urine volume and food intake in insulin-treated alloxan or streptozotocin diabetes

\begin{tabular}{|c|c|c|c|c|c|c|c|c|c|}
\hline \multirow[t]{2}{*}{ Group } & \multirow[t]{2}{*}{$\begin{array}{l}\text { No } \\
\text { of } \\
\text { rats }\end{array}$} & \multirow[t]{2}{*}{$\begin{array}{l}\text { Glucose } \\
\mathrm{mg} / 100 \mathrm{ml} \\
\text { after insulin. }\end{array}$} & \multirow[t]{2}{*}{$\begin{array}{l}\text { Acetone } \\
\mathrm{mg} / 100 \mathrm{ml} \\
\text { withdrawal }\end{array}$} & \multirow{2}{*}{\multicolumn{2}{|c|}{$\begin{array}{l}\text { Serum urea } \\
\text { mg/ } 100 \mathrm{ml} \\
\text { insulin withdrawal } \\
\text { before after }\end{array}$}} & \multicolumn{2}{|c|}{$\begin{array}{l}\text { Urine volume } \\
\text { ml/24 h } \\
\text { insulin withdrawal }\end{array}$} & \multirow{2}{*}{\multicolumn{2}{|c|}{$\begin{array}{l}\text { Food intake } \\
\text { g/ } 24 \mathrm{~h} \\
\text { insulin withdrawal } \\
\text { before after }\end{array}$}} \\
\hline & & & & & & & after & & \\
\hline $\begin{array}{l}\text { Alloxan } \mathrm{a}^{+} \\
\text {diabetes } \mathrm{b}\end{array}$ & $\begin{array}{l}5 \\
6\end{array}$ & $\begin{array}{l}407 \pm 29 \\
404 \pm 16\end{array}$ & $\begin{array}{l}18 \pm 1 \\
61 \pm 7\end{array}$ & $\begin{array}{l}7 \pm 9 \\
3 \pm 12\end{array}$ & $\begin{array}{r}41 \pm 2^{\mathrm{b}} \\
228 \pm 46^{\mathrm{a}}\end{array}$ & $14 \pm 1$ & $\begin{array}{l}109 \pm 13^{\mathrm{a}} \\
19 \pm 8^{\mathrm{b}}\end{array}$ & $\begin{array}{l}32 \pm 1 \\
27 \pm 1\end{array}$ & $\begin{array}{r}23 \pm 2^{\mathrm{b}} \\
7 \pm 1^{\mathrm{a}}\end{array}$ \\
\hline $\begin{array}{l}\text { Stropto- } a^{+} \\
\text {zotocin }\end{array}$ & 4 & $363 \pm 50$ & $18 \pm 1$ & $42 \pm 3$ & $58 \pm 10^{b}$ & $9 \pm 2$ & $115 \pm 24^{a}$ & $35 \pm 3$ & $30 \pm 8^{b}$ \\
\hline diabetes $\mathbf{b}$ & 5 & $388 \pm 38$ & $69 \pm 8$ & $50 \pm 1$ & $254 \pm 28^{\mathrm{a}}$ & $9 \pm 1$ & $13 \pm 3^{b}$ & $32 \pm 2$ & $5 \pm 1^{a}$ \\
\hline
\end{tabular}

+ Both the alloxan and streptozotocin diabetic rats were divided on the basis of blood ketone body concentration after insulin withdrawal into two groups: a) rats with blood acotone levels under $30 \mathrm{mg} \%$ and b) rats with blood acetone levels above $30 \mathrm{mg} \%$ :

Statistical evaluation: before insulin withdrawal versus after insulin withdrawal.

a $p<0.01$

b No significance

Table 3. The effect of insulin withdrawal on body weight, food intake, urine volume, serum urea and blood ketone body concentration in one alloxanized-and one streptozotocin-diabetic rat

\begin{tabular}{|c|c|c|c|c|c|c|}
\hline & \multicolumn{3}{|c|}{ Insulin-treated alloxan-diabetic rat No 1} & \multicolumn{3}{|c|}{ Insulin-treated streptozotocin-diabetic } \\
\hline & \multirow{2}{*}{$\begin{array}{l}\text { Last day of } \\
\text { insulin } \\
\text { treatment }\end{array}$} & \multicolumn{2}{|c|}{ After insulin withdrawal } & \multirow{2}{*}{$\begin{array}{l}\text { Last day of } \\
\text { insulin } \\
\text { treatment }\end{array}$} & \multicolumn{2}{|c|}{ After insulin withdrawal } \\
\hline & & 3rd day & 4th day & & 3rd day & 4th day \\
\hline $\begin{array}{l}\text { Body weight } \\
\text { g }\end{array}$ & 340 & 320 & 300 & 410 & 320 & 310 \\
\hline $\begin{array}{l}\text { Food intake } \\
\mathrm{g} / 24 \mathrm{~h}\end{array}$ & 29 & 14 & 6 & 36 & 6 & 2 \\
\hline $\begin{array}{l}\text { Urine volume } \\
\mathrm{ml} / 24 \mathrm{~h}\end{array}$ & 10 & 60 & 12 & 9 & 37 & 3 \\
\hline $\begin{array}{l}\text { Blood total ketone } \\
\text { Acetone } \mathrm{mg} / 100 \mathrm{ml}\end{array}$ & - & 25 & 82 & 一 & 30 & 48 \\
\hline $\begin{array}{l}\text { Serum urea } \\
\mathrm{mg} / 100 \mathrm{ml}\end{array}$ & 36 & 40 & 252 & 50 & 82 & 293 \\
\hline
\end{tabular}

rats which previously did not exhibit pathological findings. Blood sugar levels are not recorded in table 3 , since blood glucose was not determined on the same days as urea and ketone body concentrations.
However, necrosis of tubular epithelium was not observed. Essentially similar findings were seen in all the rats which developed uraemia, i.e. in rats with alloxan- and streptozotocin-diabetes following the 
application of the diabetogenic substances as well as 4 weeks later after insulin withdrawal. The characteristic findings in two rats with streptozotocin-induced diabetes are shown in Fig. 1 (3 days after streptozotocin application) and Fig. 2 (3 days after insulin withdrawal). namely streptozotocin, the same type of renal failure appeared in the first week after its application and also following the withdrawal of insulin. Up to date only glycogen deposition in the renal tubules has been reported in animals with long-term streptozotocin diabetes [1].

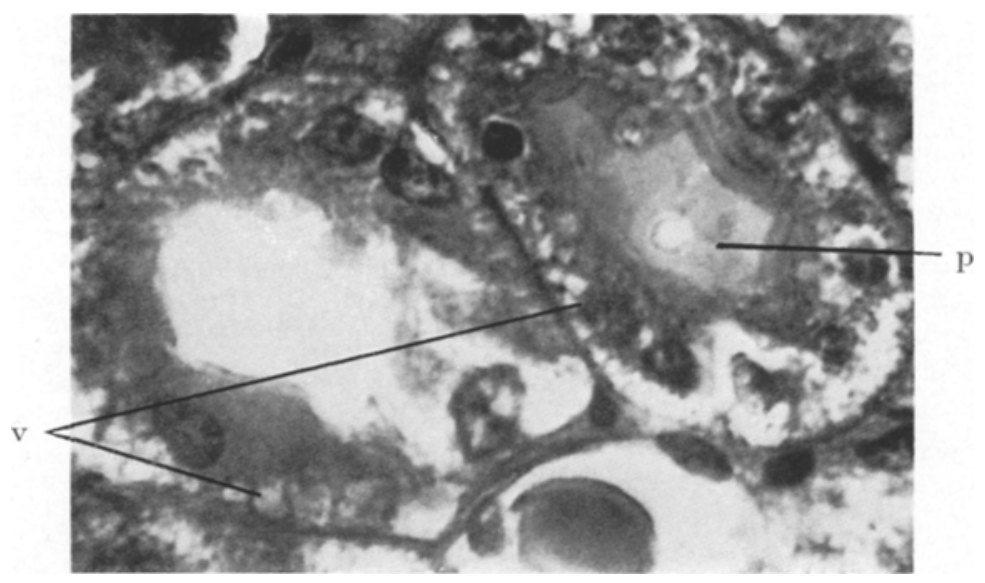

Fig. 1. A rat 3 days after streptozotocin application. Blood sugar before death $337 \mathrm{mg} / 100 \mathrm{ml}$, acetone $45 \mathrm{mg} / 100 \mathrm{ml}$ and serum urea $220 \mathrm{mg} / 100 \mathrm{ml}$. Kidney, fixation with formalin; haematoxylin and eosin; $x$ 1370. Vacuolation (v) of the tubular epithelium and protein casts $(p)$ in the tubular lumina

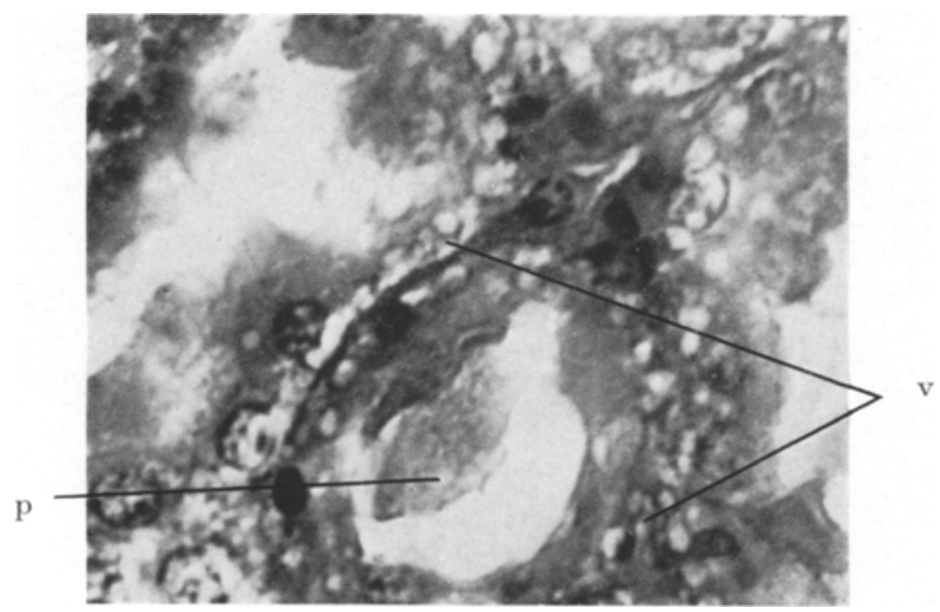

Fig. 2. A rat 31 days after streptozotocin application, treated with insulin for 28 days. Blood sugar before death $332 \mathrm{mg} / 100 \mathrm{ml}$, acetone $56 \mathrm{mg} / 100 \mathrm{ml}$ and serum urea $284 \mathrm{mg} / 100 \mathrm{ml}$ Kidney, handling and histological findings as in Fig. 1

\section{Discussion}

It is clear from our results that acute renal impairment in alloxan-diabetic rats as characterized by anuria and elevated serum urea levels is rather independent of an immediate action of alloxan. The above symptoms, attributed to renal toxicity since alloxan has been used as a diabetogenic agent, could be induced even 4 weeks after alloxan application by stopping the injection of insulin previously given. Furthermore, it is noteworthy that by using a different substance,
We have at the present no explanation for the finding that those rats which developed severe ketosis and uraemia following insulin withdrawal, showed moderately elevated average urea levels even while they were still being maintained on insulin. This finding may indicate a permanent though mild kidney damage, but also that insulin dosage was inadequate for some rats by the end of the insulin treatment. Despite the somewhat elevated initial concentration of serum urea, the increase after insulin withdrawal remains striking; and it is shown in table 3 that urae- 
mia developed in the alloxanized. rat which had no elevated concentration of serum urea during the insulin treatment.

In their recent, extensive histological study Vargas et al. [15] found severe kidney lesions mostly in the chronie state of alloxan diabetes, and although confirming alloxan toxicity they also emphasized that there are different types of renal changes in the course of this experimental diabetes.

On the basis of our present study, it cannot be concluded that alloxan or streptozotocin has no nephrotoxic effects at all. However, the elosely uniform pattern in both alloxan- and streptozotocin-diabetes, and the development of uraemia promptly following insulin withdrawal four weeks after the diabetogenio agents had been administered, permit a distinction between toxic injury and a renal failure due to acute and severe diabetes in this case. In view of the general usefulness of the two models of experimental diabetes, we feel that such a distinction is necessary.

The histological examination of the kidneys (to be published in detail elsewhere ${ }^{1}$ also showed that independently of the time at which the diabetogenic substances have been administered the morphological alterations in rats with uraemia were the same. No evidence of a direct toxic damage was found. It is noteworthy that the changes in the kidney following streptozotocin application were fairly similar to those that have been described in earlier studies on alloxan diabetes.

Acknowledgement. The authors are grateful to Dr. $\mathrm{S}$. Chernick for many helpful suggestions and to Miss Heide Czak for technical assistance.

\section{References}

1. Arison, R.N., Ciaccio, E.I., Glitzer, M.S., Cassaro, A.B., Pruss, M.P.: Light and electron mieroscopy of lesions in rats rendered diabetic with streptozotocin. Diabetes 16, $51-60$ (1967).

1 Kaufmann, F, Hohenegger, M. and Rudas, B. In preparation.
2. Benke, A., Hohenegger, M., Rudas, B.: Das Verhalten der Serumelektrolyte bei alloxandiabetischen Ratten. Wiener klin. Wschr. 83, 172-178 (1971).

3. Bessman, S.P., Anderson, M.: Estimation of citric acid and ketone bodies by the salicylaldehyde-acetone reaction. Federation Proc. 16, 154 (1957).

4. Chernick, S.S., Scow, R.O.: Early effeets of total pancreatectomy on fat metabolism in the rat. Amer. J. Physiol. 196, 125-131 (1959).

5. Fawcett, J.K., Scott, J.E.: A rapid and precise method for the determination of urea. J. clin. Path. $13,156-159(1960)$.

6. Forster, O., Rudas, B.: Ketosis in rats with streptozotocin induced diabetes. Lancet 1969 I, $1321-1322$.

7. Lennhoff, M., Herrera, J.: Acute renal failure in diabetic acidosis. Lancet 1968 I, 758 .

8. Lukens, F.D.W.: Alloxan diabetes. Physiol. Rev. 28, 304--330 (1948).

9. O'Connor, 'T.P., Schnatz, J.D.: Lipoprotein lipase activity and hypertriglyceridemia in alloxan diabetic rabbits. Metabolism 17, $838-844$ (1968).

10. Prahl, J.W., Steenrod, W.J.: Production of alloxan diabetes and ketoacidosis in the laboratory rat. Diabetes 14, 289-294 (1965).

11. Reubi, F.C.: Glomerular filtration rate, renal blood flow and blood viscosity during and after diabetic coma. Circulation Res. 1, 410-413, (1953).

12. Sadoff, L.: Effects of streptozotocin in a patient with islet cell carcinoma. Diabetes 18, 675-678 (1969).

13. Seto, D., Me Cullagh, E.P., Nakamoto, S., Kolff, W.J.: Diabetic acidosis and acute renal insufficiency. Diabetes 14, 36-37 (1965).

14. Steiner, D.F., Rauda, V., Williams, R.H.: Severe ketoacidosis in the alloxan diabetic rat. Endocrinology 68, 809-817 (1961).

15. Vargas, L., Friederici, H.H.R., Maibenco, H.C.: Cortical sponge kidneys induced in rats by alloxan. Diabetes 19, 33-44 (1970).

16. Webb, J.L.: Enzyme and Metabolie Inhibitors. p. 368. New York: Academic Press Tnc. 1966.

17. Wright, P.H.: Experimental diabetes induced by insulin antibodies. In: On the Nature and Treatment of Diabetes, pp. 354-360. Ed. Liebel, B.S., Wrenshall, G.A., Amsterdam: Excerpta Medica Foundation 1965.

18. Zimmermann, W. E.: Metabolische Azidose and Nierendurchblutung. Zbbl. f. Chir. 90, 1086-1093 (1965).

Dr. M. Hohenegger

Institute for General and Experimental

Pathology of the University of Vienna

A.1090 Vienna, Austria

Währinger Straße 13 